EGU21-6715, updated on 01 Feb 2022

https://doi.org/10.5194/egusphere-egu21-6715

EGU General Assembly 2021

(c) Author(s) 2022. This work is distributed under

the Creative Commons Attribution 4.0 License.

\title{
Structure of the SW Iberian Margin from Combined Wide-angle and Multichannel Seismic Reflection Data (FRAME Project)
}

\author{
Ricardo Correia ${ }^{1}$, Manel Prada ${ }^{2}$, Valenti Sallares ${ }^{3}$, Irene Merino ${ }^{4}$, Alcinoe Calahorrano ${ }^{3}$, Luis M. \\ Pinheiro ${ }^{1}$, and César R. Ranero ${ }^{5}$ \\ ${ }^{1}$ Department of Geosciences and CESAM, University of Aveiro, Portugal \\ ${ }^{2}$ Barcelona-CSI, Geosciences, Barcelona, Spain \\ ${ }^{3}$ Institute of Marine Sciences-CSIC, Barcelona, Spain \\ ${ }^{4}$ Barcelona Center for Subsurface Imaging, CSIC, ICM, Barcelona, Spain \\ ${ }^{5}$ ICREA at Institute of Marine Sciences-CSIC, Barcelona, Spain
}

The SW Iberian Margin has a complex tectonic setting and crustal structure derived from a succession of rift events related to the opening of North Atlantic and Neotethys from the Mesozoic to the Lower Cretaceous, and to the subsequent convergence between Nubian and Eurasian plates from Lower Oligocene to present day. Neogene plate convergence led to the reactivation of pre-existing extensional faults originated during the Mesozoic rifting in a combination of thrust and strike-slip systems. Despite a slow convergence rate, these faults now represent a major regional seismological and tsunamigenic hazard, as demonstrated by the devastating 1755 Lisbon earthquake of $M>8.5$ and the ensuing tsunami. Thus, unveiling the lithospheric structure along the SW Iberian Margin is not only important to understand the different stages of rifting and compression, but also to characterize the distribution of major lithospheric-scale boundaries, currently active and potentially capable of generating great, destructive tsunamigenic earthquakes.

To this end, we use here a spatially coincident wide-angle seismic (WAS) and multichannel seismic (MCS) data set collected along a NW-SE $\sim 320 \mathrm{~km}$ transect SW of São Vicente cape during the FRAME survey in 2018. WAS data were recorded by 24 ocean bottom seismometers and hydrophones $(\mathrm{OBS} / \mathrm{H})$ while the MCS data were recorded by a $6 \mathrm{~km}$ long, 480 channel streamer. From NW to SE, the transect runs from the Tagus Abyssal plain to the westernmost extension of the Gulf of Cadiz across four major thrust faults, namely, the Tagus Abyssal Plain fault, Marquês de Pombal fault, São Vicente fault, and Horseshoe fault.

We applied joint refraction and reflection travel-time tomography (TTT) using a combination of arrival times identified at both WAS and MCS recordings to invert for the 2D P-wave velocity (Vp) structure of the crust and uppermost mantle, as well as the geometry of the main structural boundaries identified as seismic reflectors: the top of the acoustic basement and the Moho. Combining WAS and MCS travel-times brings a remarkable increase in the resolution and accuracy of the structure of the upper layers (i.e. top of the basement) thanks to the huge increase of 
spatial sampling in the shallow parts of the crust provided by MCS data as compared to WAS data alone.

The inverted model shows a Vp structure with abrupt lateral velocity and structural variations marked by a rough Top of Basement topography and sharp changes in crustal thickness. In the northernmost part of the model there is evidence of mantle exhumation. The Moho shallows beneath the NE continuation of the Horseshoe Basin and the Gorringe Bank, coinciding with the location of the Marquês de Pombal, São Vicente, and Horseshoe thrust faults. The inversion of deep seismic phases reveals the presence of four southwest dipping reflectors that sheds new light into the deep geometry these major regional thrust faults. 